\title{
Study on University Library Subject Service Practices for Scientific Research Data Management
}

\author{
Yang Mulian ${ }^{1, \mathrm{a}}$ \\ ${ }^{1}$ Hubei University of Science and Technology Library, Xianning, Hubei, China \\ a115550482@qq.com
}

\begin{abstract}
This paper summarizes the practice of scientific research data management service in domestic and foreign university libraries, and analyzes the problems in the subject service based on scientific research data management in Chinese university libraries. Combined with the development status of Chinese subject services, this paper puts forward some suggestions on the subject service of university library oriented to scientific research data management, in order to promote the development and perfection of subject service of university library in China.
\end{abstract}

Keywords: University Library, Subject Service, Scientific research data management.

\section{INTRODUCTION}

Universities and various types of scientific research institutions have a large amount of scientific research data continuously output every year, the cleaning and screening of these data, dynamic management, sharing and preservation of the work has increasingly attracted academic attention. More and more libraries have included scientific research data services in the sustainable planning of user services.

Scientific research data is an important output in the process of academic research and an important scientific research achievement. The importance of it to scientific research is becoming increasingly prominent, has become the core resources of scientific research and innovation. In 2014, 2015 and 2017, the New Media Alliance horizon Report: Library Edition cited "increasing the focus on research data management" as a key trend in library research.

Scientific research data management refers to embedded comprehensive tracking service based on scientific data life cycle which library professional data management personnel provide. In the scientific research topic selection, research, the scientific research data management, write research papers, research results of the research activities of multiple links these librarians provide various documents and information service for scientific research personnel. Scientific research data management service can promote the reuse of data, promote the sound development of academic ecology and enhance the academic credibility of universities through the preservation, management and even sharing of scientific research data.

Under the e-science environment, domestic and foreign university libraries have carried out a lot of research and practice around scientific research data management service. This is a kind of subject service which based on the library subject service system, subject librarians are embedded in the scientific research environment to collect, sort out, mine, classify and store scientific research data, and then the processed highvalue data is shared with the scientific research workers to provide personalized information and consulting services throughout the whole data life cycle ${ }^{[1]}$.

\section{THE STATUS QUO OF SUBJECT SERVICE FACING SCIENTIFIC RESEARCH DATA MANAGEMENT IN FOREIGN UNIVERSITY LIBRARIES}

Scientific research data is a strategic scientific and technological resource with great potential in the information age. Some foreign university libraries carry out scientific research data management service earlier. In particular, universities in western developed countries such as Britain, America and Australia have carried out a lot of practices in research data retrieval, analysis, consulting, storage, sharing and data management training.

In the UK, one of the countries that proposed research data management earlier, some university libraries have taken research data management service as an important 
part of subject services. For example, subject librarians in the University of Liverpool library provide data consultation and preservation services to scientific researchers. ${ }^{[2]}$

The subject services for scientific data management in American university libraries include scientific data management introduction, scientific data management plan guidance, relevant resource recommendation, scientific data management guide, scientific data management training and consulting, etc. For example, Cornell University has set up a research data management service group to provide a variety of research data management services, including storage and backup, metadata processing, data analysis, data release, collaboration tools, etc. ${ }^{[3]}$

The subject services for scientific research data management in Australian university libraries mainly focus on data management guide and publicity service, data storage, access and sharing, reference and training, etc. For example, the website of the University of Melbourne Library elaborates the scientific research data management in detail from the aspects of Why, How, Benefits, etc., and the click rate is very high.

To sum up, the university library of the scientific research data management services in foreign countries mainly focused on the scientific research data management program, data acquisition, data management platform, training and consulting, etc., and stressed cooperation with library and scientific research units and administrative departments. Relying on key projects to build professional capabilities, formulate supporting policies and systems, and form a corresponding service product system. The service

Table 1. Survey Form of Research Data Management Service Practice in Chinese Universities

\begin{tabular}{|c|c|c|c|c|c|}
\hline $\begin{array}{l}\text { University } \\
\text { Name }\end{array}$ & $\begin{array}{l}\text { Service } \\
\text { Principal }\end{array}$ & Service Content & Service Platform & $\begin{array}{l}\text { Data Bulk (Until } \\
\text { August 2021) }\end{array}$ & $\begin{array}{l}\text { Update Time } \\
\text { (Until August } \\
\text { 2021) } \\
\end{array}$ \\
\hline $\begin{array}{l}\text { Peking } \\
\text { University }\end{array}$ & Library & $\begin{array}{l}\text { Data submission, management and } \\
\text { release; DOI permanent identifiers, } \\
\text { canonical data references; data } \\
\text { retrieval, browsing, authorized } \\
\text { downloads and comments; online } \\
\text { data analysis and visualization, } \\
\text { digital fingerprinting; version } \\
\text { archive, download statistics and } \\
\text { tracking, etc }\end{array}$ & $\begin{array}{l}\text { Peking University Open } \\
\text { Research Data Platform } \\
\text { https://opendata.pku.edu.cn/ }\end{array}$ & $\begin{array}{l}80 \text { data spaces; } \\
320 \text { data sets; } \\
2122 \text { files }\end{array}$ & $\begin{array}{l}\text { August } \\
2021\end{array}$ \\
\hline $\begin{array}{l}\text { Wuhan } \\
\text { University }\end{array}$ & Library & $\begin{array}{l}\text { Data submission, organization, } \\
\text { storage and sharing; data retrieval } \\
\text { and acquisition; construction of } \\
\text { knowledge base of scholars }\end{array}$ & $\begin{array}{l}\text { "Scientific Data Sharing } \\
\text { Platform for Universities" of } \\
\text { Wuhan University } \\
\text { http://sdm.lib.whu.edu.cn/jspui/ }\end{array}$ & 9 data sets & $\begin{array}{l}\text { Not Updated } \\
\text { Recently }\end{array}$ \\
\hline $\begin{array}{l}\text { Fudan } \\
\text { University }\end{array}$ & $\begin{array}{l}\text { Social } \\
\text { Science } \\
\text { Research } \\
\text { Center }\end{array}$ & $\begin{array}{l}\text { To collect, organize and develop } \\
\text { data on China's social and } \\
\text { economic development; providing } \\
\text { data services, teaching quantitative } \\
\text { research methods, and } \\
\text { interdisciplinary research }\end{array}$ & $\begin{array}{l}\text { Fudan University Social } \\
\text { Science Data Platform } \\
\text { http://fisr.fudan.edu.cn/ }\end{array}$ & 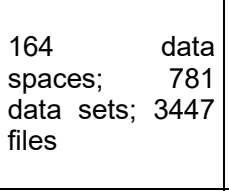 & $\begin{array}{l}\text { August } \\
2021\end{array}$ \\
\hline $\begin{array}{l}\text { Renmin } \\
\text { University } \\
\text { of China }\end{array}$ & $\begin{array}{l}\text { China } \\
\text { Survey and } \\
\text { Data Center }\end{array}$ & $\begin{array}{l}\text { Retrieve data, store data, manage } \\
\text { data, analyze data }\end{array}$ & $\begin{array}{l}\text { Chinese Academic Survey } \\
\text { Data Base } \\
\text { http://cnsda.ruc.edu.cn/ }\end{array}$ & Article 800 & $\begin{array}{l}\text { January } \\
2018\end{array}$ \\
\hline $\begin{array}{l}\text { Hunan } \\
\text { University }\end{array}$ & $\begin{array}{l}\text { Institute of } \\
\text { Economic } \\
\text { and Trade }\end{array}$ & $\begin{array}{l}\text { Education and training, data } \\
\text { sharing, investigation and analysis, } \\
\text { data mining, decision-making } \\
\text { consultation }\end{array}$ & $\begin{array}{l}\text { Data Management System of } \\
\text { Economic Data Research } \\
\text { Center of Hunan University } \\
\text { http://edrc.hnu.edu.cn/ }\end{array}$ & Article 324 & March 2019 \\
\hline
\end{tabular}

system of "policy-organization-utilization-training" as the main axis has been formed for scientific research data management. The network mechanism of internal and external collaboration expands the influence of the service, and enables the subject service to be sustainably embedded in the scientific research data management process.

\section{THE STATUS QUO AND EXISTING PROBLEMS OF SUBJECT SERVICE FACING SCIENTIFIC RESEARCH DATA MANAGEMENT IN UNIVERSITY LIBRARIES IN CHINA.}

\subsection{The present situation of subject services for scientific research data management in University libraries in China}

At present, the scientific research data management service in China is still in its infancy and has not carried out large-scale data management practice. We found that only Peking University, Wuhan University, Fudan University, Renmin University of China and Hunan University have launched scientific research data management services and built scientific research data management and sharing platforms, as shown in the table. Although some university libraries do not provide scientific research data management service on their websites, they will provide some data support in the scientific research support module. Most university libraries have access to navigation and retrieval services, but none have access to data management plan support services. The specific analysis is as follows: ${ }^{[4]}$ 
(1) The basic services for scientific research data management are constantly developing. First, to carry out data literacy training and set up relevant courses for scientific research data management; the second is to provide retrieval service in scientific research data management by focusing on the needs of researchers for specific scientific research data management.

(2) Responsible for the effective preservation of scientific research data and policy formulation. One is to participate in the construction of research data policy and system; second, to serve the development of scientific research data standards; third, the development of scientific research data processing services.

(3) Carry out subject services for scientific research data association. The existing research data platforms and tools should be studied, and the paper information, patent information and policy information should be connected with the research data to form a broader data network. We study the connection between the two to find more knowledge points, support the research management and improve the scientific research innovation ability.

There are three kinds of subject services for scientific research data management in university libraries: (1) Special website service. With the university library website as the platform, it provides scientific research data management service publicity, and assists users to formulate online scientific research data management plan and network learning resources. (2) Scientific research reference service. Through multiple channels, such as university library website, email, wechat, microblog, telephone, face-to-face and other channels, answer users' questions in the process of using scientific research data in detail. (3) Education and training services. University libraries carry out online and offline professional training in data backup, utilization, retrieval, sharing and other aspects to improve data literacy, so as to enhance users' ability to manage and use scientific research data. ${ }^{[5]}$

\subsection{Problems existing in the Subject services for scientific research data Management in China's University libraries $^{[6]}$}

(1) Insufficient research on data management practices

As early as 2001, China's Ministry of Science and Technology launched the scientific data sharing project, and a total of 24 departments in earth science, resources and environment, population and health, basic and frontier fields have carried out research data management practices. However, institutions of higher learning still lack of attention to research data management, only a few first-class universities or scientific research institutions to provide research data management services. Moreover, the utilization rate of research data management platform in some universities is not high, and even has been invalid.
(2) Lack of research data management policies

In March 2018, China issued Measures on the Management of Scientific Data, which is the first national research data management policy. According to the survey, most of the domestic university libraries that have carried out research data management services have not formulated special research data management policies, norms and sharing policies. The lack of research data management policies at the institutional level leads to the lack of systematic and normative research data management in China's universities.

(3) The main role of library in research data management is not prominent

At present, only a few universities in China provide research data management services by library. The actual situation is that research data management services in some universities in China are provided by colleges or other scientific research institutions, which will also affect the audience of services and reduce the utilization rate of service resources.

(4) Single service mode, service content to be enriched

Institutions which has carried out the research data management service in China failed to provide data management design and planning services, few data analysis service. Data literacy training organization are fewer in view of the scientific research personnel, less interaction between scientific research personnel and subject (data) librarians, especially the lack of face-toface communication, communication channels need to be expanded.

\section{SUBJECT SERVICE STRATEGIES FACING SCIENTIFIC RESEARCH DATA MANAGEMENT IN CHINESE UNIVERSITY LIBRARIES ${ }^{[6]}$}

\subsection{Formulate research data management policies for colleges and universities}

Under the environment of E-science, China needs to formulate well-structured scientific research data management policies to provide support and guarantee for the development of scientific research data management. The research data management policy should be divided into three levels: "the state, the funding institutions and the universities", and step by step. As one of the main bodies of scientific data management stipulated in Measures on Scientific Data Management, universities should formulate research data management policies suitable for their research environment at the micro level, such as the specific operation and implementation plan of research data management. These policies should be more specific, including data management plans, data scope, data standards, data 
sharing and retention, and data security and ownership. The policy should also establish the main role of the library in the research data management service, integrate the research data management service into the subject service system, give full play to the advantages of the library in the subject service, so as to provide efficient research data management service for researchers and improve the efficiency of scientific research.

\subsection{Technology guidance: Build a well- functioning scientific research data management service platform}

Content is king, technology is wing. Relying on cloud storage technology, visualization technology, Internet of things technology, artificial intelligence, free open source software, data mining technology, data security technology and other technical means, the service quality and effect can be improved, which has been proved in the practice of foreign university libraries. University libraries should lead the construction of research data warehousing and one-stop research data service platform. The platform supports data upload and acquisition, and provides functions such as data retrival, metadata processing and analysis, as well as various research data management tools and data literacy education videos. The platform should also provide security guarantee for data storage and sharing to ensure long-term storage and continuous management of user data, and formulate sustainable development strategies to ensure the reliability, adaptability and scalability of the system platform.

\subsection{Improve service personnel's professional quality and strengthen institutional cooperation}

At present, few university libraries in China set up scientific research data management teams and lack highquality data librarians. The scientific research data management work of university libraries is mostly undertaken by subject librarians and information technology department personnel. University libraries should carry out special training on research data management for subject librarians to improve their data business literacy and equip them with relevant skills of data management, such as data storage, backup, migration, analysis, sharing and metadata processing. And through the means of incentive and assessment to encourage the professional quality and service ability of the librarians to improve themselves, to train a team can carry out scientific research data management services. At the same time, the complexity of data management needs other departments to provide some support for the library. For example, the information service department provides spatial support for data storage, and the scientific research management department provides information related to scientific research projects. The formation of the service mechanism with the library as the leading and multi-department cooperation is more conducive to the smooth development of the research data management service.

\subsection{Precise positioning of service demand, and construction of personalized and characteristic service system}

Researchers with different academic backgrounds have different demands on scientific research data management services. The premise of carrying out scientific research data management service in library is to fully understand the service needs of scientific research personnel, combine different scientific research data service environment and subject background, and provide customized personalized service for scientific research personnel of different disciplines and majors. Embedded in the user space of scientific research, improve the interaction between library and scientific research personnel, and provide scientific research data management services matching supply and demand. The service mode should be detailed, and dedicated personnel should be assigned to assist researchers to develop metadata, provide text mining services, and help researchers to transform spatial data. To build a scientific research data management service system composed of service demand, service platform, service content, service mode and service effect, and provide individualized, targeted and satisfactory scientific research data management services for researchers. ${ }^{[7]}$

\subsection{Build guidance website and set scientific research support column to integrate and navigate service projects}

Library website is an important portal for library to provide services. University libraries can set up a special scientific research support column on the home page of the website to collect all scientific research support services and set clear navigation to improve user efficiency. The content generally covers data management, data retention, data sharing and archiving, ethics, intellectual property, and policy, covering a range of processes in data management services, with detailed recommendations, practices, and troubleshoots in each section.

\section{CONCLUSION}

Big data era, emphasis on "data is king", as the library is the "growing" organism, so the subject services should also be a "growing" organism. The library brings "scientific research data management" into the subject services, which opens up a new field of university library knowledge service, expand the new direction of university library in the future business. Libraries should seize the opportunity and make innovations to promote 
the integrated development of scientific research management work and subject service work.

\section{ACKNOWLEDGMENTS}

This paper is supported by the Research Fund Program of Hubei Academic Library Committee in 2019 (Project no. : 2019-ZD-05) "Research on Embedded Scientific Research Service Mode and Content of University Library in Ubiquitous Knowledge Environment”.

\section{REFERENCES}

[1] Xu Kun, Cao Jindan. University libraries participate in the research of scientific data management [J].Library Forum, 2014,34 (5):92-98.

[2] Zhang Yuhan, Liz Waller, Vanya Gallimore, et al. Investigation and analysis of subject services in British university libraries [J].Journal of Library and Information Service,2017(11):63-70.

[3] Liu Fang. Research on information service innovation of university library in the era of big data [M]. Beijing: Guangming Daily Press, 2016

[4] Lu Ying. Research on subject service of university library oriented to scientific research data management $[\mathrm{J}]$. Library Work and Study ,2021,(3):41-48.

[5] Guan sifa. Research on key elements and realization model of big data knowledge service [J].Library Forum, 2015, (6):87-93.

[6] Li Yang, Pei Li. Research on the subject service mode of university library oriented research data management [J]., 2020,(6):112-117.

[7] Zhang Guixiang, Liu Guifeng, Liang Wei. A review of research data management theory and service in China [J]. Information Theory \& Practice,2020,43(06):187-193. 